\title{
Transatlantica
}

Revue d'études américaines. American Studies Journal

\section{Film and Art : On the German Expressionist and the Disney Exhibitions}

\section{Penny Starfield}

\section{Q OpenEdition \\ 1 Journals}

\section{Édition électronique}

URL : http://journals.openedition.org/transatlantica/1192

DOI : 10.4000/transatlantica. 1192

ISSN : 1765-2766

Éditeur

AFEA

\section{Référence électronique}

Penny Starfield, «Film and Art : On the German Expressionist and the Disney Exhibitions », Transatlantica [En ligne], 2 | 2006, mis en ligne le 23 janvier 2007, consulté le 29 avril 2021. URL : http:// journals.openedition.org/transatlantica/1192 ; DOI : https://doi.org/10.4000/transatlantica. 1192

Ce document a été généré automatiquement le 29 avril 2021

\section{(c) (i) (9)}

Transatlantica - Revue d'études américaines est mis à disposition selon les termes de la licence Creative Commons Attribution - Pas d'Utilisation Commerciale - Pas de Modification 4.0 International. 


\title{
Film and Art : On the German Expressionist and the Disney Exhibitions
}

\author{
Penny Starfield
}

Le Cinéma expressionniste allemand, La Cinémathèque française, curators:

Marianne de Fleury and Laurent Mannoni, October 26, 2006-January 22, 2007.

Il était une fois Walt Disney, aux sources de l'art des studios Disney, curator : Bruno Girveau, Le Grand Palais, September 16, 2006-January 15, 2007 ; Musée des Beaux-

Arts, Montréal, 8 March-24 June 2007.

1 Two major exhibitions in Paris delve into the relationship between the artistic and the film worlds. The German Expressionists in Film celebrates the seventieth anniversary of the French Cinémathèque, founded by Henri Langlois in 1936. It is housed in the temporary exhibition space on the fifth floor of the recently-inaugurated Cinémathèque, which moved from its historic site at the Palais de Chaillot to the luminous building conceived by Frank Gehry on the far eastern side of the right bank. On display are some of the treasures of the Cinémathèque's collection of paintings and sketches by little-known scenic artists and art directors, the Filmarchitekte, who helped the German directors in the conception of their films. The exhibition is accompanied by a comprehensive retrospective of German expressionist films and a special retrospective devoted to director Friedrich W. Murnau. Once upon a time in the world of Disney at the Grand Palais is a much larger and detailed exhibition, concentrating on the European influences on the famous filmmaker and the team of animators who worked for him. It reveals that, contrary to popular belief, Walt Disney possessed a wealth of cultural knowledge and took much of his inspiration from different artistic and literary sources.

German expressionism in film developed from the artistic movement of the same name and was fostered by the despair and horror of the First World War. It coincides with the Weimar Republic and the creative spirit of the time. Centered essentially in Berlin, expressionism brought together the finest of German directors, technicians and actors and its influence went far beyond geographical and temporal boundaries. Definitions 
vary, but basically expressionism sought to depict an inner reality. Artistically, it was a reaction to the dominant movements at the turn of the century-impressionism, Art Nouveau, etc.-beginning with the founding of the Brücke group in Dresden in 1905 and continued through the creation of the Blaue Reiter group in 1908. In film, it is generally seen as a reaction to realism, but the more restrictive definition confines expressionism to a period ranging from 1919-1924, comprising films that continue the style developed by Robert Wiene's The Cabinet of Dr Caligari (1919) with its artificial lighting and crooked scenery. Broader definitions include other theatrical and filmic tendencies of the time, such as the Kammerspiel and the Neue Sachlichkeit, the New Objectivity. The former was generally associated with Max Reinhardt-appointed to the head of the Berlin Deutsches Theater in 1905-who was to influence theater and film in Europe and the United States for several generations. It covers the twenties in film and includes Murnau's The Last Laugh (1924) and Georg Wilhelm Pabst's The Joyless Street (1925). Pabst's films were also close to the Neue Sachlichkeit, which favored a return to a form of realism as a reaction to a tendency to pseudo-expressionism.

3 The current exhibition adopts the broader approach, grouping artworks and films thematically under five main headings: Nature, Interiors, The Street, Staircases, and The Body. It situates the films within the political and cultural context of the time as of 1905, enabling the inclusion of earlier films such as Paul Wegener's The Student of Prague (1913) and The Golem (1914), both of which were remade during the expressionist period proper. Expressionism terminated in 1933 with the Nazis' coming to power. Joseph Goebbels was appointed Minister of Propaganda and Information and the clamp down began. An autodafé of books was organized and the forced or voluntary departure of many artists, writers and filmmakers followed, among them Reinhardt and art historian and film critic Lotte Eisner, who later became one of Langlois' special collaborators. The Cinémathèque is greatly endebted to Eisner for their collection. It was due to her relentless searching in the wake of the Second World War, through her efforts to track down the Filmarchitekte, that many of the works were acquired. In an interview for the catalogue to the exhibition, Werner Herzog describes how Eisner was the link between the past and the present for the generation of young directors who had been alienated from their own culture by Nazism and who formed the "New German Cinema" in the 60s and 70s. His film, Nosferatu, Phantom of the Night (1978), extracts of which are shown toward the end of the exhibition, pays homage to this heritage.

4 The exhibition's thematic approach allows for a comprehensive study of German film of the period. Wandering through the first area, one is reminded that nature was especially present in the earlier films and that the directors were seeking to transpose their German heritage, to be found in sources as diverse as myths or legends like The Niebelungen (Fritz Lang, 1924), the Romanticism of Goethe's Faust (Murnau, 1926) or German landscape painting which sought to convey the expressions of the soul and which forms the setting for several films. A taste for the fantastic appeared in Murnau's Nosferatu (1922) and for science fiction in Lang's Woman in the Moon (1929) or in his Metropolis (1927) with its dystopian vision. Gradually the scene shifted to the city and contemporary society, often presenting ordinary people awash in a harsh, everyday world as in The Last Laugh and the Pabst films.

5 The sketches and paintings are carefully annotated, generally with an additional commentary by Eisner or other specialists on the particular aspect under discussion. 
Extracts from films and stills enable one to compare the preparatory sketches with the finished product. Frequently, indications for the set or for filming were added in, so that in many ways the drawings worked as storyboards. Erich Kettelhut's sketch for the Niebelungen dragon, showing a construction that would be worked from the inside by a team of ten men, provides detailed instructions for its functioning. Next to it, a gouache by Otto Hunte of the dragon drinking at a stream shows how the artists worked in conjunction on a single film. The drawings stand out because many of them are artistic productions in their own right. The Interiors section, presents Emil Hasler's ink drawing of the trial scene in Lang's $M$ (1931). The squashed faces of the characters are reminiscent of an Ensor painting. In Otto Hunte's sketch for Lola Lola's dressingroom in The Blue Angel (Joseph von Sternberg, 1930), the cabaret singer has the angular face of an Otto Dix portrait, revealing a stark divergence with the finished product. Yet, if Marlene Dietrich supplied the outer fleshy and sensual forms, the drawing expresses the hard, inner traits of the character. Whether as artistic works or as intermediaries of contemporary artistic currents, these drawings reveal the sources of inspiration for the expressionist films. Indeed they contain the very methods used by the directors in their creative process. During his later American period, Lang, for example, continued to make extensive use of preparatory sketches, many of them his own work.

6 Through their use of strongly contrasted black and white photography, of extensive tracking shots (The Last Laugh) and crooked interiors that expressed the inner workings of the mind and soul, of twentieth century's move to facism (Lang's films), the German expressionists were in fact reinventing film. The Staircase section concentrates on a pictural motif that allowed tortured souls to give external expression to their feelings. Staircases were also important scenic and diegetic elements and later films continue to explore their possibilities. Among the interesting material in the Body area is the poster proposed by Paul Sheurich for Lang's The Testament of Dr Mabuse (1933). It was never used because the film was banned by Goebbels. It shows a head incrusted with a smaller head between the eyes and nose, expressing a cross-section of the real self, or a fitting illustration of thought police. The relationship between the filmmakers and the Nazi regime falls into a murky area. To begin with, it would seem, Goebbels admired the "Germanic" element in their work and sought to co-opt them, successfully in some cases. Generally the main filmmakers preferred to expatriate. European and American cinema inherited a wealth of directors, cinematographers, art decorators and actors. Indeed, four years later, expressionism figured amongst the "degenerate" arts decried by Goebbels in an exhibition of that name.

7 German expressionist film had some influence during its time. Alfred Hitchcock, for example, made a couple of films at the German studios in the mid-twenties. The United States had been interested in German film and theater from an earlier date: Reinhardt brought his productions to Broadway regularly as of 1912 and Caligari was released in the US in 1921. Hollywood soon extended invitations to the film directors. It is said that Murnau gave a lighter ending to The Last Laugh with an eye to American audiences, yet his first "American" film, Sunrise (1927), despite its mainly American team and cast, bears a strong expressionist imprint. Screenwriter Carl Mayer had first attracted attention with Caligari and written several screenplays for expressionist films, notably that of The Last Laugh. Art director Rochus Gliese had collaborated on films such as Wegener's 1920 version of The Golem, and his drawings for Sunrise are featured in the current exhibition. Gliese made another film in Hollywood and then returned to Germany. Indeed, the mass exodus of the thirties concerned few of the Filmarchitekte 
and though some kept a low profile during the war, others such as Walter Röhrig remained active in Third Reich film. Nevertheless, Eisner's task was facilitated by the fact that most of them were still in Germany after the war and in contact with one another.

Douglas Fairbank Sr. claims to have been inspired by the oriental characters in Paul Leni's Wax Museum (1924) for The Thief of Bagdad (Raoul Walsh, 1924). The Body section of the exhibition displays a number of interesting character sketches for the former film by costume designer Ernst Stern who, like Leni, had formerly worked with Reinhardt. One of them depicts Ivan the Terrible, played by Conrad Veidt who, amongst his varied roles, was acclaimed in expressionist films such as Caligari and Wiene's 1924 Orlac's Hands. Eisner saw the character in Leni's film as the model for Sergei Eisenstein's Ivan the Terrible (1944/1958), corroborated by the sketch and film stills. We are reminded in the Disney exhibition that Eisenstein was also influenced by Fantasia (1940) in the making of his film. Leni's Hollywood career was brief as he died in 1929 and is most known for The Man Who Laughs (1928). Bob Kane, the creator of the comic book Batman series (1939), claims to have modelled The Joker on Veidt's character in this film. Interestingly, Tim Burton's Batman (1989) is one of the examples given in the exhibition for expressionist influence on more recent films, along with David Cronenberg's Spider (2002).

The influences and interactions between the German expressionists and other cinemas are endless, and many are only now coming to light. The original perspective of this exhibition will help further exploration in the area. One wonders, for example, if Walt Disney and his animators had access to Stern's Wax Museum sketches of Harun al Rachid, the Calif, a eunuch and a guard. These sketches bear the mark of caricature and seem to announce future Disney creations. The dark hair, heavy eyebrows and pointed beards and moustaches may have found their way to the more villainous characters. One has the impression that Disney animators consulted the expressionist sketches for some of their later work, such as the 1992 animated feature, Aladdin. Or is the "orientalism" in this film multi-layered, the result of intricate sources, one of which would be The Thief of Bagdad (and its later remake)? Likewise, the sketch for The Testament of Dr Mabuse by Walter Schulze-Mittendorf, who also designed the robot for Metropolis. Here the infamous Mabuse with his starting eyes, electrified hair and long neck appears the image of madness. Is it too far-fetched to see a likeness between this sketch and some of the digitalized ghosts that feature in recent Disney live action productions such as The Haunted Mansion (Rob Minkoff, 2003) and Pirates of the Caribbean (Gore Verbinski, 2003)?

10 It is of great interest therefore to discover the extent to which the Disney films owe a direct or indirect debt to German expressionist cinema. The Disney exhibition is in many ways complementary to the other exhibition, but it also allows a greater insight into the workings of the animator and filmmaker. One tends to associate Walt Disney with the commercial side of his enterprise, forgetting his humble beginnings in animation. His later career was also clouded by reports of his authoritarian rule and his staunch anti-Communism during the McCarthy era. Disney became synonomous with sentimentality and conventionality; the earlier, innovatory nature of his work was overshadowed by more daring and subversive animations like those by Tex Avery. The present exhibition derives much from Robin Allen's seminal work on the European artistic influences on the maestro. It begins with Steamboat Willie (1928), the first short 
animation with syncronized sound featuring Disney's most famous creation, Mickey Mouse, and ends with The Jungle Book (1967), the last animated feature film conceived during Disney's lifetime and released a year after his death.

11 Not only did Disney have a penchant for the classics and fairy tales such as those of Perrault and the brothers Grimm, he also amassed a collection of illustrated books and paintings from the nineteenth and early twentieth century. On his 1935 visit to Europe alone, he acquired about 300 books, many of them original editions, and brought them to the Disney studios. Animators were free to consult works of French illustators and artists like J. J. Granville, Honoré Daumier and Gustave Doré or, from England, Arthur Rackam's fantastical illustrations and John Tenniel's and F.D. Bedford's famous illustrations for Lewis Carroll's Alice in Wonderland and James Barrie's Peter Pan and Wendy respectively. Disney also favored the German illustrator of Grimm's Fairy tales, Ludwig Richter, and Heinrich Kley whose elephant drawings influenced Dumbo (1941). Paintings from the Pre-Raphaelites and the German landscape artists are also present. It now becomes evident that what one may have taken as a vague European influence in the rounded fairy-tale turrets of Sleeping Beauty's castle was based intentionally on actual works: the illuminations of the Très Riches Heures du Duc de Berry, drawings by French architect Viollet-le-Duc and Louis II's fantastical castles in Bavaria.

12 The exhibition also pays tribute to the many artists who worked for Disney, like Ub Iwerks, with Disney the creator of Mickey Mouse. Some were brought over from Europe, like the Swedish artist Gustaf Tenggren, who gave a Germanic aspect to the settings in Pinocchio (1940), and the Danish Kay Nielsen, who provided many of the inspirational paintings for Fantasia. Others were Americans with a vast knowledge of European culture, like Joe Grant who left his imprint on Snow White and the Seven Dwarfs (1937), or Mary Blair, who worked on post-war features like Cinderalla (1950), Alice (1951) and Peter Pan (1953), carefully studying the illustrated works of these stories.

13 Richter's illustrations for Grimm's Snow White depict the heroine in idyllic settings, surrounded by little birds and deer. Dogs and cats figure in other drawings. We find here one of the sources for the myriad animals to be found in Disney animations. Disney's fascination with the animal kingdom is revealed by his interest early on in Edweard Muybridge's photographic experiments on human and animal locomotion. Later editions of Muybridge's Animals in Motion(1887) and The Human Figure in Motion(1887) figure in the collection. As the exhibition points out, the anthropomorphic strain running through Disney's cartoon characters can be traced back to fables, such as those from Aesop or La Fontaine. The phenomenon was accentuated through the illustrations of the nineteenth century. So, while naturalists from Buffon to Darwin were categorizing species through serious drawings and diagrams, illustrators like Grandville and Ernest Griset were producing humorous images of exaggeratedly drawn animals-hybrids and invented creatures that took people back to the Medieval world of imagined monsters. Some late nineteenth century paintings featured in the exhibition show an interest for fabulous creatures like centaurs. Indeed, these figured in short animations of the late teens, and Disney was to use them in Fantasia. In his use of animals, Disney also drew from a tradition that was being established in animated films. The exhibition presents a short film by one of the pioneers of American animation Winsor McCay, featuring Gertie the Dinosaur. Gertie, the first animated star, made her appearance in 1914. One can add other animated animals, such as George Herriman's popular Krazy Kat (from 1916 onwards), who was accompanied by a smart 
little mouse called Ignatz, Tom Sorg's Almanach, which featured a circus of animals, or Willis O'Brien's figurines, first shown in The Dinosaur and the Missing Link (1917). As the exhibition points out, O'Brien was to use these techniques in the live action films The Lost World (1925) and King Kong (1933)

One of the highlights of the exhibition is to be found in the second room where a large screen on the right presents extracts from a live action feature film while a similar screen on the left shows the Disney counterpart. Thus Disney's short animation The Mad Doctor (1933) has Mickey strapped to an operating table while a range of machines are set up by a gesticulating, fiendish doctor. On the right, we view James Whale's Frankenstein (1931), in which the doctor of the same name is preparing his creation in similar, if less exaggerated fashion. Or again, in Modern Inventions (1937) Donald Duck is fed by a host of mechanical arms and legs, in imitation of Chaplin's Modern Times (1936). Pet Story (1933) presents a parody of King Kong: a gorilla who has escaped from his cage stands on a pile of boxes of pet food grasping a trembling Minnie in his paw. Pet-shop birds, instead of airplanes, come to the rescue, jabbing maliciously at the gorilla's head. The humor in these films is the greater when contrasted with the original and must have been obvious to viewers at the time. It emerges that certain animal depictions were being established, some of them based on age-old stereotypical ideas. Others were being formulated through cartoons and comics, such as the dumb cat and the astute little mouse, to which more topical interpretations were sometimes attributed. The gorilla in The Pet Shop appears big, friendly and stupid, a characteristic frequently attributed to monkeys and from which racist connotations were not exempt.

On the more somber side, several of the clips are taken from German expressionist films. Caligari and Wax Museum are indeed a fitting reference for The Sorcerer's Apprentice episode in Fantasia, based on a poem by Goethe. Expressionism can be seen in the contrast between the little mouse and the immense, abstract decor, the winding stairs which are paralleled with the staircase in the $1920 \mathrm{Golem}$, the use of shadow to present a threatening presence off-screen. Another comparison is made between the bat in Murnau's Faust (1926) and the shadow that engulfs the screen in The Bald Mountain episode. Further interactions with live action film are presented during the exhibition: Joan Crawford provided one of the models for the Wicked Queen in Snow White while her transformation into a witch after taking a magic potion was based on Rouben Mamoulian's Jekyll and Hyde (1931). The Blue Fairy in Pinocchio was modelled on Jean Harlow.

The exhibition also presents Destino, from the attempted collaboration between Salvador Dali and Disney. It was finally edited as short film in 2003. As with the German Expressionists exhibition, influences on later artistic works are shown, among them artists such as Christian Boltanski, Bertrand Lavier, Peter Saul, Erró and Gary Baseman. Each person will add his or her own particular reference. The happy conjunction of the two exhibitions can only bring cinephiles and researchers closer to an understanding of the creative process. Indeed both exhibitions provide concrete evidence that the transmission of images owes less to some sort of vague "collective unconscious" than to tangible cultural interactions. 


\section{BIBLIOGRAPHIE}

The classics: Eisner, Lotte H., L'Ecran démoniaque: les influences de Max Reinhardt et de l'expressionnisme (Paris: [André Bonne, 1952] Ramsey-Poche Cinéma, Ramsay, 1985) (English translation: The Haunted Screen: Expressionism in the German Cinema and the Influence of Max Reinhardt (London: Signet Press, 1973)).

Kracauer, Siegfried, From Caligari to Hitler, A Psychological History of the German Film (Princeton : Princeton University Press, [1947] 1974(.

Re-publication of the classic Murnau by Charles Jameux, Paris [1965], “7e Art”, Cerf-Corlet, 2006.

The excellent catalogues of both exhibitions, and the following recent publications provide extensive bibliographies:

Le Cinéma expressionniste allemand, splendeurs d'une collection (Paris : Coédition Cinémathèque française/Éditions de La Martinière, 2006). Articles by B. Eisenschitz, L. Eisner, T. Elsaesser, M. de Fleury, L. Mannoni, D. Robinson.

Il était une fois Walt Disney: Aux sources de l'art des studios Disney, Bruno Girveau (ed.) (Paris: RMN, 2006). Articles by B. Girveau, L. Smith, C. Solomon, R. Allan, H. Crawford, Dominique Païni, P. Lambert.

Allan, Robin, Walt Disney and Europe: European Influences on the Animated Feature Films of Walt Disney (London: John Libbey, 1999).

Bourget, Jean-Loup, Hollywood, un rêve européen (Paris: Armand Colin, 2006).

Cerisuelo, Marc, Vienne et Berlin à Hollywood: Nouvelles approches (Paris: Presses Université de France, 2006). Articles by M. Cerisuelo, P. Berthomieu, J.-L. Bourget, B. Eisenschitz, V. EleftériouPerrin, T. Elsaesser, F. Lignon, J. Nacache, C. Neyrat, C. Viviani.

Floquet, Pierre (ed.), CinémAnimationS (Condé-sur-Noiret: “CinémAction,” Corlet, March 2007).

INDEX

Thèmes : Trans'Arts 